http://dx.doi.org/10.12775/szhf.2018.032

\author{
JOANNA USAKIEWICZ
}

Uniwersytet w BiaŁymstoku, BiaŁystok, Polska

E-MAIL: JOANNA.USAKIEWICZ@ONET.EU

\title{
Damaris Masham, jej związki z Johnem Lockiem i dyskusja z Gottfriedem Wilhelmem Leibnizem*
}

Damaris Cudworth Masham (1659-1708) to jedna z bardziej znanych siedemnastowiecznych myślicielek ${ }^{1}$. Córka filozofa Ralpha Cudwortha (16171688), jednego z tak zwanych platoników z Cambridge. Zaprzyjaźniona z Johnem Lockiem (1632-1704), który w domu Damaris i jej męża, Francisa

* Praca naukowa finansowana ze środków Ministra Nauki i Szkolnictwa Wyższego w ramach dotacji na utrzymanie potencjału badawczego przyznanej Wydziałowi Filologicznemu Uniwersytetu w Białymstoku.

${ }^{1}$ Na temat życia i dzieła Damaris Cudworth Masham vide: George Ballard, Memoirs of Several Ladies of Great Britain, Who Have Been Celebrated for Their Writings Or Skill in the Learned Languages Arts and Sciences (Oxford: Printed by W. Jackson, 1752), 379-388; Henry Richard Fox Bourne, The Life of John Locke. In Two Volumes (New York: Harper \& Brothers Publishers, 1876), vol. 2, 210-215; The Correspondence of John Locke. In Eight Volumes, red. Esmond Samuel de Beer (Oxford: At the Clarendon Press, 1976 - ), vol. 2, 470-472; A History of Women Philosophers. Volume III: Modern Women Philosophers, 1600-1900, red. Mary Ellen Waithe (Dordrecht/Boston/London: Kluwer Academic Publishers, 1991), 73-85; Jacqueline Broad, Women Philosophers of the Seventeenth Century (Cambridge: Cambridge University Press, 2004), 114-140. 
Masham (ok. 1649-1723)², spędził ostatnie lata życia. Miłośniczka mądrości, która wyrażała swoje poglądy zarówno w pismach wydawanych drukiem, jak w prywatnej korespondencji między innymi ze wspomnianym Johnem Lockiem, teologami: Philippem van Limborchem (1633-1712) i Jeanem Le Clerc (1657-1736) oraz Gottfriedem Wilhelmem Leibnizem (1646-1716). Niniejszy tekst stanowi próbę ukazania jej jako samodzielnej, krytycznej myślicielki, zainteresowanej zarówno spekulacją filozoficzną, jak kwestiami społecznymi, na podstawie jej dwóch opublikowanych pism: Discourse Concerning Love of God oraz Occasional Thoughts in Reference to a Vertuous or Christian Life, jak również jej korespondencji z G.W. Leibnizem.

Jako córka filozofa Damaris Cudworth Masham miała dostęp do zamkniętej dla większości kobiet jej współczesnych szerszej i na wyższym poziomie edukacji. Jej szczególny intelekt już w dzieciństwie odkrył ojciec i to on zajmował się jej kształceniem. Mogła także przysłuchiwać się dyskusjom prowadzonym przez ojca z innymi filozofami i uczonymi. We wczesnych już latach miała dać się także poznać światu jako osoba wyróżniająca się „niezwykłą wiedzą i pobożnością" (uncommon learning and piety) ${ }^{3}$. John Locke, którego znajomość z Damaris Cudworth rozpoczęła się około $1681 \mathrm{roku}^{4}$, wyraził swoją opinię o niej między innymi w liście do Ph. van Limborcha z 13 marca 1690/91 roku, w którym, podkreślając jej znajomość teologii i filozofii, pisze, że niewielu zna mężczyzn, którzy przewyższaliby ją wiedzą. Zwrócił uwagę na jej zdolność do rozwiązywania trudnych i zawiłych kwestii filozoficznych i teologicznych. Nie omieszkał też wspomnieć o jej słabym wzroku. Locke napisał:

Pani ta tak oddaje się studiom i rozmyślaniom teologicznym i filozoficznym, że nie znajdziesz kilku ludzi, z którymi obcowałbyś z większą korzyścią i przyjemnością. Przede wszystkim posiada bardzo staranny osąd i znam niewielu, którzy rozprawiają i rozwiązują trudności z tak wielką jasnością co do rzeczy bardzo zawiłych i dalekich od zdolności pojmowania, nie mówię, kobiet, lecz także większości wykształconych mężów. Tej, która niegdyś oddawała się czę-

${ }^{2}$ Damaris Cudworth poślubiła sir Francisa Masham, trzeciego baroneta Oates (Essex), członka Parlamentu w 1685 roku. Była jego drugą żoną. Francis Masham z pierwszego małżeństwa miał dziewięcioro dzieci, z Damaris zaś jednego syna - Francisa Cudwortha Masham (ochrzczony 1686 r.)

${ }^{3}$ Ballard, Memoirs of Several Ladies of Great Britain, 379. Należy zaznaczyć, że są to wszystkie informacje dotyczące jej edukacji.

${ }^{4}$ Treść listów vide: The Correspondence of John Locke. 
stej lekturze, teraz stoi na przeszkodzie słabość oczu, co aż nadto uzupełnia przenikliwość umysłu .

Zanim w 1691 roku Locke zamieszkał w domu Damaris i Francisa Masham ${ }^{6}$ prowadził z panią domu korespondencję, $\mathrm{w}$ której między innymi podejmowane były kwestie filozoficzne ${ }^{7}$. W jednym $z$ listów (9 marca 1682) zwraca uwagę wyznanie Masham, że nie ma nieprzychylnej opinii o platonizmie, ponieważ obraca się wśród platoników, których zawsze znajdowała jako ludzi wielu cnót, a także jako przyjaciół ${ }^{8}$. Przyczyna jest więc czysto subiektywna, nie odnosi się do samych ich poglądów. Fakt, że wychowywała się wśród ludzi o bardzo sprecyzowanych poglądach filozoficznych, nie spowodował, iż przyjęła je bezkrytycznie. W 1688 roku (7 kwietnia) Damaris Masham napisała zaś do Locke’a, chwaląc pomysł dokonania skrótu jego Rozważań dotyczacych rozumu ludzkiego (An Essay Concerning Human Uderstanding), jako osoba, która ze względu na bardzo słaby wzrok miała trudności z czytaniem obszernych dzieł filozoficznych. W liście wyraziła też szczególne zainteresowanie kwestią idei wrodzonych, podkreślając różnicę między poglądem, iż konkretne idee są człowiekowi wrodzone, a przekonaniem, że są one obecne jako an active sagacitie in the soul („aktywna przenikliwość w duszy”) 9 .

Inną osobą mającą szczególnie wysokie zdanie o przymiotach intelektualnych Masham był John Norris (1657-1711), duchowny i filozof, zwolennik okazjonalizmu Nicolasa Malebranche’a (1638-1715) i krytyk empiryzmu

${ }^{5}$ Domina ipsa ita in Theologis philosophisque studiis et contemplationibus versata est ut paucos invenias homines quibuscum maiore cum fructu et iucunditate verseris: Limatissimi imprimis est iudicii. paucosque novi qui tanta cum perspicuitate de rebus abstrusissimis et a captu non dico faeminarum sed etami plerorumque literatorum remotis $<$ disserant $>$ et difficultates $<$ solvant $>$. Lectionem cui olim multum erat dedita iam impedit oculorum imbecillitas, cui abunde supplet mentis acies; The Correspondence of John Locke, vol. 4, 237-238 (nr 1375). (Przekłady na język polski, jeśli nie podano inaczej, Joanna Usakiewicz.)

${ }^{6}$ Do przeprowadzki do Oates skłonił Locke’a stan zdrowia. Początkowo właściwie rezydował u Mashamów z przerwami na pobyty w Londynie ze względu na zaangażowanie w sprawy publiczne i sprawowane funkcje. Pod koniec życia posiadłość w Oates stała się jego domem, w którym zmarł, a lady Masham towarzyszyła mu w ostatnich godzinach życia, czytając psalmy.

${ }^{7}$ Masham podpisywała listy do Locke’a imieniem Philoclea, które prawdopodobnie zaczerpnęła z romansu pasterskiego Philipa Sidney’a The Countess of Pembroke's Arcadia (1590) (vide The Correspondence of John Locke, vol. 2, 473, przyp. 1).

${ }^{8}$ Vide The Correspondence of John Locke, vol. 2, 493 (nr 690).

${ }^{9}$ Ibidem, vol. 3, 433 (nr 1040). Słowo sagacitie (od łacińskiego sagacitas) można by tłumaczyć także jako „bystrość” lub „rozsądek”. 
Lockea. W 1688 roku zadedykował jej swoją pracę Theory and Regulation of Love, podkreślając samodzielność intelektualną Masham ${ }^{10}$. Komplementował ją także w wydanych w 1690 roku Reflections upon the Conduct of Human Life. Dobre stosunki między Masham a Norrisem zostały jednak zerwane i miało to związek zarówno z kwestiami osobistymi, jak i różnicą poglądów. Jako powody osobiste wskazuje się dwie kwestie. Po pierwsze, we wspomnianych Reflections... Norris napisał ${ }^{11}$, że Masham nie widzi, choć ona, jak wspomnieliśmy, miała tylko bardzo słaby wzrok. Po drugie, Locke oskarżył Norrisa, że złamał on pieczęć na jednym z jego listów do Masham ${ }^{12}$. Różnica poglądów zaś dotyczy przede wszystkim rozumienia miłości oraz Boga jako jedynej przyczyny wszystkiego, i ma związek z pierwszym opublikowanym, co prawda anonimowo, w roku 1696 pismem Masham: Discourse Concerning Love of God $^{13}$ (Rozprawa dotyczaca miłości do Boga).

Polemikę między Masham a Norisem zapoczątkowało wydane w 1695 roku w Londynie pismo: Letters Concerning the Love of God Between the Author of the Proposal to the Laidies and Mr. John Norris: Werein his late Discourse, shewing that is ought to be intire and exclusive of All other Loves, is further cleared and justified ${ }^{14}$. Wspomniany autor The Proposal to the Laidies ${ }^{15}$ to Mary Astell (1666-1731), również znana ówczesna angielska myślicielka. Poglądy zawarte w owych Letters... stały się przyczyną napisania przez Masham krytycznej odpowiedzi właśnie w postaci Discourse Concerning Love of God. W rozważaniach możemy doszukać się nawiązań do Locke’a oraz teologa

${ }^{10}$ Vide John Norris, Theory and Regulation of Love. A Moral Essay in Two Parts (Oxford: Printed at the Theatre for Hen. Clements, 1688), dedykacja na początku książki bez numeracji stron.

${ }^{11}$ Vide John Norris, Reflections upon the Conduct of Human Life (London: Printed for S. Manship at the Black Bull in Cornhil, 1690), 3 et sequentes.

${ }^{12}$ Vide Broad, Women Philosophers of the Seventeenth Century, 118.

13 [Damaris Masham], Discourse Concerning Love of God (London: Printed for Awnsham and John Churchil, at the Black-Swan in Pater-noster-Row, 1696).

${ }^{14}$ Letters Concerning the Love of God Between the Author of the Proposal to the Laidies and Mr. John Norris: Werein his late Discourse, shewing that is ought to be intire and exclusive of All Rother Loves, is further cleared and justified (London: Published by John Norris, 1695).

${ }^{15}$ [Mary Astell], A Serious Proposal to the Laidies, for the Advancement of Their True and Greatest Interest By a Lover of Her Sex (London: Printed for R. Wilkin at the King's Head in St. Paul's Church, 1694). 
i uczonego, późniejszego krytyka poglądów Locke’a, Edwarda Stillingfleeta $(1635-1699)^{16}$.

Jednym z głównych tematów Letters... jest miłość. Astell i Norris rozumieją miłość jako poruszenie duszy ku dobru. Wyróżniają dwa rodzaje miłości: miłość życzliwości (benevolence) oraz miłość pragnienia/pożądania (desire/concupiscence). Rozróżnienie to wynika z przedmiotu miłości. Pierwszą z wymienionych miłości człowiek kocha wszelkie stworzenie, jest to miłość bezinteresowna motywowana altruizmem i chęcią czynienia dobra. Na drugą zasługuje jedynie Bóg. Człowiek pragnie Boga jako swojego dobra. Bóg nie potrzebuje ludzkiej życzliwości, stworzenie zaś nigdy nie usatysfakcjonuje ludzkiego pragnienia.

Masham krytykuje taki podział miłości, przedstawia również odmienną jej definicję. Miłość jest „pewnym prostym działaniem umysłu” (one simple act of the mind) ${ }^{17}$, który człowiek odnajduje w sobie wobec tego wszystkiego, co mu sprawia przyjemność, co go zadowala. Tym, co sprawia człowiekowi przyjemność może być zarówno drugi człowiek, jak i wszelkie inne stworzenie. Masham pisze: „Jeśli kwiat równie w jakiś sposób sprawia przyjemność (jak z pewnością sprawia), to jest on także równie upragniony"18. I w innym miejscu: „Kiedy mówię, że kocham moje dziecko lub mojego przyjaciela, znajduję, iż rozumiem to tak, że są oni rzeczami, które sprawiają mi przyjemność, te byty są dla mnie zadowoleniem"19. Możemy odnaleźć tu nawiązanie do myśli Locke’a, wyrażonej w Rozważaniach dotyczących rozumu ludzkiego: „Tak więc, istnienie i dobrobyt naszych dzieci lub przyjaciół sprawia nam ustawiczną rozkosz, a wówczas mówi się, że kochamy je. Wystarczy jednak zaznaczyć, że nasze idee o miłości i nienawiści są tylko usposobieniami umysłu w stosunku do przyjemności i cierpienia w ogóle, jakkolwiek bądź

\footnotetext{
${ }^{16}$ E. Stillingfleet należał do tak zwanych „tolerancjan” (latitudinarians), którzy ukształtowali się wśród platoników z Cambridge. Obok tolerancji głosili, że życie moralne jest istotą chrześcijaństwa, a rozum ludzki jest zdolny poznać prawdę o Bogu.

${ }^{17}$ Vide [Masham], Discourse Concerning Love of God, 24. W innym miejscu czytamy: „Miłość będąca jedynie nazwą nadaną usposobieniu lub działaniu umysłu, które odnajdujemy w sobie wobec wszelkich rzeczy, które sprawiają nam przyjemność" (Love being only a name given to the disposition or act of the mind, we find in our selves towards any thing we are pleas'd with [...]; ibidem, 18).

${ }^{18}$ If the flower is either way equally pleasing (as certainly it is) then it is also equally desireable; ibidem, 32 .

${ }^{19}$ When I say that I love my child, or my friend, I find that my meaning is, that they are things I am delighted in; their being is a pleasure to me; ibidem, 18.
} 
wywołanych"20. W odróżnieniu od Locke’a pozostaje Masham przy podziale miłości. Życzliwość i pragnienie wypływają z miłości zależnie od jej przedmiotu i okoliczności. Masham uważa, że stworzenie może być przez człowieka kochane zarówno miłością życzliwości, jak i pragnienia, co odróżnia ją od Astell i Norrisa. Kochamy wszak nasze dzieci miłością pragnienia, gdy są daleko od nas, ale jednocześnie przecież życzymy im dobrze ${ }^{21}$. Wszelkie stworzenie może zarówno stanowić dla człowieka dobro, jak to dobro od niego otrzymywać. Bogu jako dobru najdoskonalszemu należy się najwyższa miłość i uwielbienie: „Kiedy mówię, że kocham Boga ponad wszystko, znajduję, iż wyjaśniam to tym, że jest On moim najwyższym dobrem i mam w Nim przyjemność ponad wszystko inne"22.

Zaprzeczając istnieniu idei wrodzonych, a co za tym idzie także wrodzonych zasad moralnych, Masham wskazuje, że człowiek musi nabyć ideę miłości. Człowiek musi więc najpierw doświadczyć uczucia przyjemności w interakcji z innymi stworzeniami, aby dzięki refleksji nabyć ideę miłości, a mając ideę miłości, może kochać także Boga. Czytamy: „Jak dzięki istnieniu stworzenia zaczynamy wiedzieć, że jest Stworzyciel, tak urok stworzeń jest tym, dzięki czemu zaczynamy poznawać taki sam urok ich Stworzyciela i zaczynamy Go kochać"23. Człowiek nie rodzi się z poczuciem obowiązku kochania Boga. Może kochać Boga po tym, jak kocha innych ludzi: „Jeśli nie kochalibyśmy stworzeń, niepojęte byłoby, jak moglibyśmy kochać Boga"24. Człowiek został przeznaczony przez Boga do życia społecznego. Masam kwestia ta wydaje się bezdyskusyjna: „Nie ma niczego bardziej oczywistego niż to, że rodzaj ludzki został stworzony do życia społecznego"25.

\footnotetext{
${ }^{20}$ Thus the being and welfare of man's children or friends producing constant delight in him, he is said constantly to love them. But it suffices to note, that our ideas of love and hatred are but the dispositions of the mind, in respect of pleasure and pain in general, however caused in us; John Locke, An Essay Concerning Human Understanding (Dublin: Printed for T. Tegg and Son, 1836), 147 (2, 20, 5). Przekład na język polski za: John Locke, Rozważania dotyczace rozumu ludzkiego, tłum. Władysław Mieczysław Kozłowski (Warszawa: Hachette, 2011), 261-262.

${ }^{21}$ Vide [Masham], Discourse Concerning Love of God, 23 et sequentes.

${ }^{22}$ When I say that I love God above all, I find I would express that he is my chiefest Good, and I delight in him above all things; ibidem, 18.

${ }^{23}$ For as by the existence of the creatures, we come to know there is a Creator, so by their loveliness it is that we come to know that of their author and to love him; ibidem, 65.

${ }^{24}$ And if we lov'd not the Creatures, it is not conceiveable how we should love God [...]; ibidem, 62 .

${ }^{25}$ There is nothing more evident than that Mankind is design'd for a Sociable Life; ibidem, 123.
} 
Masham podkreśla, że poglądy Norrisa i Astell są nieprzydatne na płaszczyźnie etycznej, ponieważ nie opierają się na codziennym doświadczeniu człowieka, na zdrowym rozsądku (common sense) ${ }^{26}$. Nawiązuje tu do Stillingfleeta, podkreślającego, że wszelkie objaśnienia świata, zarówno teologiczne, jak i filozoficzne, powinny odpowiadać zdrowemu rozsądkowi.

Bardzo istotną kwestią, którą podejmuje Masham w Discourse Concerning Love of God w nawiązaniu do poglądów Norrisa, jest krytyka okazjonalizmu. Jeżeli uważamy, że stworzenia są okazjonalną, a nie sprawczą przyczyną naszych wrażeń, to:

mądrość Boga nie może wobec tego być równie podziwiana, ponieważ nie jest równie widoczna. Gdyby Bóg bezpośrednio pokazał mi wszystkie moje idee, a więc nie widziałabym prawdziwie moimi oczyma, nie słyszałabym za pomocą moich uszu, wtedy cała cudowna dokładność i zadziwiająca fachowość w budowie organów zmysłowych, wydałaby się zbyteczna i próżna, co przynosiłoby nie mało znaczącą ujmę nieskończonej mądrości ${ }^{27}$.

Masham uważa więc, że jeżeli byty stworzone nie są przyczynami sprawczymi, tylko Bóg bezpośrednio przedstawia naszej duszy idee, to skomplikowana budowa naszych organów zmysłowych jest jakimś rodzajem nieprzydatnej sztuki. Pogląd, że Bóg jest jedyną przyczyną sprawczą, prowadzi też według Masham do wniosku, iż musiał On zaprogramować człowieka także do grzesznych pragnień, czyli Bóg jest „partnerem naszej niegodziwości” (a partner in our wickedness) ${ }^{28}$. Te same argumenty wysuwać będzie przeciw koncepcji przedustawnej harmonii Leibniza. Zanim jednak przejdziemy do korespondencji z Leibnizem, zwrócimy uwagę na jeszcze jedną myśl zawartą w omawianym piśmie. Chodzi o komentarz do przytoczonych przez Masham słów Malebrancha z Conversations chrétiennes ${ }^{29}$, w których łączy on wszelkie skłonności człowieka do tego, co materialne, z faktem narodzenia $\mathrm{z}$ kobiety. Kobieta ma w sobie pewne inklinacje ku zmysłowości. Dziecko w jej łonie doświadcza tego samego, stąd przychodzi na świat jako grzesznik. Masham

\footnotetext{
${ }^{26}$ Vide ibidem, 39 et sequentes. dom; ibidem, 32 .

${ }^{28}$ Ibidem, 102.

${ }^{29}$ Ibidem, 71 et sequentes.
}

${ }^{27}$ (...) the wisdom of God cannot herein be equally admired, because it is not equally conspicuous. For if God immediately exhibits to me all my idea's, and that I do not truly see with my eses, and hear with my ears; then all that wonderful exactness and curious workmanship, in flaming the organs of sense, seems superfluous and vain; which is no small reflection upon infiniti wis- 
odrzuca te poglądy, twierdząc, że jeżeli Bóg jest Stwórcą wszystkiego, stworzył też nas takimi, że odczuwamy różne przyjemności, a więc jest odpowiedzialny również za stworzenie pożądania cielesnego każdego człowieka - nie jest ono wyłącznie związane z kobietą.

Korespondencja między Masham a Leibnizem, na którą składa się w wydaniu Gerhardta dwanaście listów, została zainicjowana przez Leibniza ${ }^{30}$. Pierwszy list Leibniz napisał w grudniu roku 1703 lub na początku 1704 roku, ostatni najprawdopodobniej pod koniec 1705 roku. Leibniz pisał w języku francuskim, Masham zaś po angielsku. Leibniz zwraca się do Masham w związku z tym, że dowiedział się, iż ma ona zamiar przesłać mu książkę swojego ojca True Intellectual System of the Universe (Ściśle rozumowy opis świata; 1678) $)^{31}$. Pochlebnie wypowiada się o jej autorze i systemie, dodając, że sam ma pewne uzupełnienia do jego poglądów i odsyła do ich omówienia dokonanego przez Pierre’a Bayle’a (1647-1706) w jego Dictionnaire historique et critique ${ }^{32}$. Dodaje też, iż ma bardzo dobrą opinię o umysłowości angielskich dam, wymieniając z nazwiska Anne Conway (1631-1679) ${ }^{33}$. Jak

${ }^{30}$ Korespondencja w: Gottfried Wilhelm Leibniz, Die Philosophischen Schriften, red. Carl Immanuel Gerhardt (Berlin: Weidmanniche Buchhandlung, 1960), vol. 3, 336-375 (dalej cytowane jako G numer tomu, numer strony) oraz Leibniz's New System and Associated Contemporary Texts, red. Roger Woolhouse, Richard Francks (Oxford: Clarendon Press, 1997), 202-225 (obszerne fragmenty z przekładem listów Leibniza na język angielski).

${ }^{31} \mathrm{~W}$ piśmie tym Cudworth wskazuje między innymi, że człowiek posiada ideę Boga, jak również wielu innych rzeczy, których nie postrzega zmysłowo. Nie można odrzucić istnienia czegoś tylko dlatego, że nie postrzegamy tego naszymi zmysłami. Nie możemy co prawda pojąć Boskiej doskonałości, ale posiadamy ideę bytu doskonałego. W świecie stworzonym mamy do czynienia z różnymi szczeblami natury. Cudworth odrzuca całkowitą dychotomię między światem cielesnym a duchowym. Zwierzę nie jest rodzajem maszyny, posiada czującą duszę. Zajmując się ludzkim poznaniem, twierdzi, że są dwa rodzaje „percepcyjnych myśli”: bierne, które są wrażeniami zmysłowymi lub obrazami oraz aktywne, które powstają z samego umysłu (idee, sądy). Choć zmysły odgrywają pewną rolę w poznaniu rzeczy, nie dają znajomości ich istoty ani nie przynoszą prawdy naukowej. Vide Frederick Copleston, Historia filozofii. Od Hobbesa do Hume'a, tłum. zbiorowe, (Warszawa: Instytut Wydawniczy PAX, 1997), vol. 5, 67 et sequentes. Vide także: Sławomir Raube, Deus explicatus. Stworzenie i Bóg w myśli Ralfa Cudwortha (Białystok: Wydawnictwo Uniwersytetu w Białymstoku, 2000).

${ }^{32}$ Vide Pierre Bayle, Dictionnaire historique et critique. Tome Seconde. Seconde Partie P-Z (Rotterdam: Chez Reinier Leers, 1697), 967 (nota H). Bayle odwołuje się do poglądów Leibniza w kontekście Girolamo Rorario (Rorariusa) i jego broszury Quod animalia bruta ranione utantur melius homine (1548).

${ }^{33}$ Anne Conway - angielska myślicielka, zaprzyjaźniona z Henrym Morem (1614-1687), jednym z platoników z Cambridge, autorka dzieła Zasady filozofii najstarszej i najnowszej, zawierającego przemyślenia metafizyczne, na które wielki wpływ miało jej osobiste doświadczenie 
wynika z odpowiedzi Masham, będzie ona wykorzystywać wymianę listów z Leibnizem do pogłębienia swojej wiedzy, co jest zgodne z jej przekonaniem, że każdy człowiek, zarówno mężczyzna, jak i kobieta, został obdarzony przez Boga zdolnościami poznawczymi, rozumem, a zatem jego powinnością jest doskonalenie się na drodze kształcenia. Napisała, że zapoznała się z tekstem Bayle’a, ale również przeczytała Système Nouveau de la nature et de la Communication des substances, aussi-bien que de l'union qu'il y a entre l'âme \& le corps wydany w Le Journal des sçavans ${ }^{34}$. W kolejnych listach Masham przedstawia właściwie swoje streszczenia poglądów Leibniza zawartych w Nowym systemie natury i wzajemnej łączności substancyj, jak również związku istniejącego między dusza a ciałem ${ }^{35}$ i robi to tak dobrze, że w liście z 30 czerwca 1704 roku Leibniz napisał, że jasność i odpowiedniość jej wyjaśnień są takie, iż będzie mógł z nich skorzystać, aby przekazać swoją myśl innym. Czytamy: „[...] podziwiam celność i jasność Pani wyrażeń w przedmiocie tak abstrakcyjnym. Są one takie, że przyniosą mi samemu pożytek innym razem, gdy będzie chodziło o to, abym wyjaśnił to komuś innemu"36.

Nie znaczy to, że Masham we wszystkim zgadzała się z poglądami Leibniza. Krytykuje koncepcje przedustawnej harmonii. W liście z 3 czerwca 1704 roku wskazuje, iż pogląd ten powoduje, że cała wspaniałość i precyzja organów cielesnych staje się czymś zbędnym i bezużytecznym: „[...] organizację ciała, w której całą tę ładną dziwność odnajdujemy jako wydającą się bezużyteczną, jako będącą zbytecznym i próżnym trudem" ${ }^{37}$. Przytacza więc ten sam argument, którego wcześniej użyła, krytykując okazjonalizm. $\mathrm{W}$ odpowiedzi na to Leibniz twierdzi z przekonaniem, że nawet gdyby w całej naturze była tylko jedna dusza, na przykład Cezara, stworzyciel musiałby przydać jej organy cielesne. Poza tym ciało jest według niego rodzajem świata

cierpienia cielesnego. Vide: Joanna Usakiewicz, Bonum et (im)mutabilitas. Myśl filozoficzna Anne Conway (1631-1679) (Białystok: Trans Humana, 2002) oraz Anne Conway, Zasady filozofii najstarszej i najnowszej, tłum. Joanna Usakiewicz (Kraków: Aureus, 2002).

${ }^{34}$ Vide Le Journal des sçavans, XXVI (4 Juillet 1695): 301-306 oraz G 4, 471 et sequentes.

${ }_{35}$ Przekład na język polski Stanisław Cichowicza w: Goottfried Wilhelm Leibniz, Pisma z metafizyki natury, red. Seweryn Blandzi, tłum. Zbiorowe (Toruń: Wydawnictwo Rolewski, 1999), 25-37.

${ }^{36}$ (...) jadmire la justesse et la netteté de vos expressions dans une materie si abstraite. Elles sont telles que j’en profiteray moy même une autre fois quand il s'agira de m'expliquer à quelcun; G 3, 352.

${ }^{37}$ (...) the organization of the body, wherein all that nice curiositie that is discoverable seeming useless, becomes superfluous and lost labour; G 3, 350. 
pełnego nieskończenie wielu stworzeń, z których każde zasługuje na istnienie. Leibniz pisze:

Odpowiadam, że jeśliby dusza Cezara (na przykład) była jedyną w naturze, Stworzyciel rzeczy musiałby dać jej organy cielesne. [...] Nasze ciało jest rodzajem świata pełnego nieskończonej ilości stworzeń, które także zasługują na istnienie, i gdyby nasze ciało nie było złożone z organów cielesnych, nasz mikrokosmos, czyli mały świat, nie miałby całej doskonałości, którą mieć powinien, a wielki świat nie byłby tak bogaty, jak jest ${ }^{38}$.

Kolejny problem, według Masham, polega na tym, że Leibniz na określenie podstawowych form substancjalnych wśród różnych innych terminów posługuje się też określaniem „siły pierwotne” (forces primitives). Siła według Masham: „nie może być istotą żadnej substancji, lecz jest atrybutem tego, co ty nazywasz "formą», "duszą» lub "atomem substancjalnym»"39. Leibniz w odpowiedzi zaznacza, że nie rozumie siły jako istoty substancji, ale jako zasadę działania (principe d'action) ${ }^{40}$.

Masham podważa także możliwość istnienia substancji nierozciągłej: "Jeśli umiejscowienie tych substancji tłumaczy się [samym] ich istnieniem zawsze, jak mówisz, w zorganizowanym ciele, to są one gdzieś; lecz jeśli te «atomy substancji» są gdzieś, to muszą mieć jakąś rozciągłośćc ${ }^{41}$. Według Masham także nie mając wyobrażenia takiej substancji, nie możemy mówić o jej istnieniu. Rozciągłość „jest dla mnie nierozdzielna od pojęcia wszelkiej substancji" (is to me inseparable from the notion of all substance ${ }^{42}$. Leibniz odpowiada, że fakt, iż nie mam wyobrażenia nierozciągłej substancji, nie oznacza, że nie mam jej pojęcia, i odsyła do Locke’a. Czytamy: „Mogę uwierzyć, Pani, że nie masz wcale wyobrażenia substancji nierozciągłej, lecz to wcale nie

\footnotetext{
${ }^{38}$ Je reponds que si l'ame de Cesar (par exemple) devoit estre seule dans la nature, Lauteur des choses auroit pû se passer de luy donner des organes. (...) Nostre corps est un espece de monde plein d'une infinité de creatures qui meritoient aussi d'exister, et si nostre corps n'estoit pas organisé, nostre Microcosme ou petit monde n'auroit pas toute la perfection qu'il doit avoir, et le grand Monde même ne seroit pas si riche qu'il est; G 3, 356.

${ }^{39}$ (...) cannot be the essence of any substance, but is the attribute of what you call a "form", „soul”, or „atome de substance”; G 3, 350.

${ }^{40} \mathrm{G} 3,356$.

${ }^{41}$ If the localitie of these substances were accounted for by theire being, as you [say] they are, always in organiz'd bodies, then they are somewere: but if these "atomes de substance" are somewere, then they must have some extension; G 3, 350 .

${ }^{42} \mathrm{G} 3,359$.
} 
przeszkadza, abyś miała jej pojęcie. Pan Locke podzielił mój pogląd w swoich Rozważaniach, i skoro odwiedza Panią, niesłusznie podejmowałbym się tego, co on zrobi lepiej i bezpośrednio" ${ }^{43}$.

Drugie pismo Masham, Occasional Thoughts in Reference to a Vertuous or Christian Life (Myśli okazjonalne w związku z cnota i życiem chrześcijańskim), zostało wydane w 1705 roku, podobnie jak pierwsze anonimowo ${ }^{44}$. Jest ono najlepszym wyrazem poglądów społecznych Masham. Zwraca bowiem w nim uwagę na problem edukacji kobiet. Kobiety są zdolne do kształcenia się, co więcej konieczność ich edukacji wynika zarówno z porządku boskiego, jak dobra społeczeństwa. Bóg w swej mądrości nie obdarzyłby kobiet rozumem, gdyby nie chciał, aby z niego korzystały i go doskonaliły poprzez uczenie się. Kobiety należy edukować, ponieważ jako matki są pierwszymi nauczycielkami dzieci obu płci. Masham pisze: „Doskonalenie rozumu wszelako konieczne jest dla ogłady dam jako racjonalnych stworzeń; i jakkolwiek potrzebne dla dobrej edukacji ich dzieci, a też dlatego, aby były użyteczne dla swoich rodzin" ${ }^{45}$. Kobiety są też pierwszymi przekazicielkami zasad religijnych. Brak wykształcenia sprawia, że ich wiara opiera się na zwyczaju, a nie na zrozumieniu, a to powoduje, że zarówno one, jak ich dzieci nie są w stanie bronić wiary, a nawet poprzez niezrozumienie jej podstaw popadają w bezbożność. Czytamy: „Jeśli chrześcijaństwo jest religią od Boga, i kobieta ma duszę do zbawienia tak samo jak mężczyzna, wiedzieć z czego ta religia się składa i rozumieć podstawy, na jakich jest przyjmowana, jest bardziej niż konieczną wiedzą dla kobiet, tak jak i dla mężczyzn" ${ }^{46}$. Masham jest także przeciwna podwójnym standardom moralnym: innym dla mężczyzn, innym dla kobiet. Szczególnie zwraca uwagę na wymaganą od kobiet cnotę czystości, która po pierwsze, skupia się tylko na cielesności, usprawiedliwiając niejako

\footnotetext{
${ }^{43}$ Je veux bien croire, Madame, que sous n'avés point d'image d'une substance non-etendue; mais cela n'empeche point que vous en pussiés avoir une notion. M. Lock estant de mon sentiment selon son Essay et se trouvant chez vous, jaurois tort d'entreprendre ce qu'il peut mieux faire et de pres; G 3, 362. Vide John Locke, Rozważania dotyczace rozumu ludzkiego, 2, 22, 2.

${ }^{44}$ [Damaris Masham], Occasional Thoughts in Reference to a Vertuous or Christian Life (London: Printed for A. and J. Churchil at the Black Swan in Pater-noster Row, 1705).

${ }^{45}$ The improvements of reason, however requisite to ladies for their accomplishment, as rational creatures; and however needful to them for the well educating of their children, and to their being useful in their familie; ibidem, 161-162.

${ }^{46}$ For if Christianity be a religion from God, and women have souls to be saved as well as men; to know what this religion consists in, and to understand the grounds on which it is to be received, can be no more than necessary knowledge to a woman, as well as to a man (...); ibidem, 165-166.
} 
społeczne przyzwolenie na podtrzymywanie ignorancji umysłowej kobiet, po drugie, wskazuje, iż czystość jest obowiązkiem obu płci.

Dodajmy, że przekonanie o istotności kształcenia kobiet dla edukacji dzieci widoczne jest u Masham nie tylko w jej teoretycznych rozważaniach. Locke w liście do irlandzkiego filozofa Williama Molyneux (1656-1698) z 28 sierpnia $1693 \mathrm{roku}^{47}$ bardzo podkreślał jej niezmierne zaangażowanie w edukację syna oraz osiągnięcia na tym polu, pisząc, że dziewięcioletni syn Masham, Francis, bardzo dobrze czyta i pisze, zna geografię, chronologię, system Kopernika oraz umie mnożyć i dzielić.

Damaris Cudworth Masham, choć blisko związana z jednej strony z platonikami z Cambridge, z drugiej z Johnem Lockiem, była myślicielką samodzielną. To przykład kobiety przezwyciężającej ograniczenia swojej epoki. Społeczeństwo, w którym przyszło jej żyć, nie sprzyjało kształceniu i rozwojowi intelektualnemu kobiet. Te nieliczne, które wchodząc w dyskurs z uczonymi mężami swych czasów, dotrzymywały im pola, doceniało, choć uważało za ewenement, czego dowodem może być epitafium poświęcone Damaris Masham. Czytamy w nim między innymi: „Która do delikatności i wytworności swojej własnej płci dodała kilka szlachetniejszych umiejętności i przymiotów płci przeciwnej”48.

\section{Bibliografia}

[Astell Mary]. 1694. A Serious Proposal to the Laidies, for the Advancement of Their True and Greatest Interest By a Lover of Her Sex. London: Printed for R. Wilkin at the King's Head in St. Paul's Church.

Ballard, George. 1752. Memoirs of Several Ladies of Great Britain, Who Have Been Celebrated for Their Writings Or Skill in the Learned Languages Arts and Sciences. Oxford: Printed by W. Jackson.

Bayle, Pierre. 1697. Dictionnaire historique et critique. Tome Seconde. Seconde Partie P-Z. Rotterdam: Chez Reinier Leers.

Broad, Jacqueline. 2004. Women Philosophers of the Seventeenth Century. Cambridge: Cambridge University Press.

\footnotetext{
${ }^{47}$ Vide Fox Bourne, The Life of John Locke, vol. 2, 267.

${ }^{48}$ Who to the Softness and Elegance of her own Sex added several of the Noblest Accomplishments and Qualities of the other; cyt. za: Ballard, Memoirs of Several Ladies of Great Britain, 388.
} 
Conway, Anne. 2002. Zasady filozofii najstarszej i najnowszej. Tłum. Joanna Usakiewicz. Kraków: Aureus.

Copleston, Frederick. 1997. Historia filozofii. Od Hobbesa do Hume’a. Tłum. zbiorowe. Vol. 5. Warszawa: Instytut Wydawniczy PAX.

The Correspondence of John Locke. In Eight Volumes. 1976-1989. Red. Esmond Samuel de Beer. Oxford: At the Clarendon Press.

Fox Bourne, Henry Richard. 1876. The Life of John Locke. In Two Volumes. New York: Harper \& Brothers Publishers.

A History of Women Philosophers. Volume III: Modern Women Philosophers, 1600-1900. 1991. Red. Mary Ellen Waithe, Dordrecht/Boston/London: Kluwer Academic Publishers.

Leibniz Gottfried Wilhelm. Die Philosophischen Schriften. 1960. Red. Carl Immanuel Gerhardt. Vol. 3-4. Berlin: Weidmanniche Buchhandlung.

Leibniz Gottfried Wilhelm. 1999. Pisma z metafizyki natury. Red. Seweryn Blandzi, tłum. zbiorowe. Toruń: Wydawnictwo Rolewski.

Leibniz Gottfried Wilhelm. „Système Nouveau de la nature et de la Communication des substances, aussi-bien que de l'union qu'il y a entre l'âme \& le corps". Le Journal des sçavans, XXVI (4 Juillet 1695): 301-306.

Leibniz's New System and Associated Contemporary Texts. 1997. Red. Roger Woolhouse, Richard Francks. Oxford: Clarendon Press.

Letters Concerning the Love of God Between the Author of the Proposal to the Laidies and Mr. John Norris: Werein his late Discourse, shewing that is ought to be intire and exclusive of All Rother Loves, is further cleared and justified. 1695. London: Published by John Norris.

Locke John. 1836. An Essay Concerning Human Understanding. Dublin: Printed for T. Tegg and Son.

Locke John. 2011. Rozważania dotyczace rozumu ludzkiego (ks. 1-2). Tłum. Władysław Mieczysław Kozłowski, Warszawa: Hachette.

[Masham Damaris]. 1696. Discourse Concerning Love of God. London: Printed for Awnsham and John Churchil, at the Black-Swan in Pater-noster-Row.

[Masham Damaris]. 1705. Occasional Thoughts in Reference to a Vertuous or Christian Life, London: Printed for A. and J. Churchil at the Black Swan in Paternoster Row.

Norris John. 1690. Reflections upon the Conduct of Human Life. London: Printed for S. Manship at the Black Bull in Cornhil.

Norris John. 1688. Theory and Regulation of Love. A Moral Essay in Two Parts. Oxford: Printed at the Theatre for Hen. Clements.

Raube Sławomir. 2000. Deus explicatus. Stworzenie i Bóg w myśli Ralfa Cudwortha. Białystok: Wydawnictwo Uniwersytetu w Białymstoku.

Usakiewicz Joanna. 2002. Bonum et (im)mutabilitas. Myśl filozoficzna Anne Conway (1631-1679), Białystok: Trans Humana. 


\section{Abstract \\ Damaris Masham, Her Connexions with John Locke and Discussion with Gottfried Wilhelm Leibniz}

This article attempts to present Lady Damaris Masham as an individualistic thinker in the context of her own works and the correspondence with Gottfried Wilhelm Leibniz.

Damaris Masham (1659-1708) was the daughter of Ralph Cudworth, one of the Cambridge Platonists. She was a friend of John Locke, who spent last years of his life at her home at Oates in Essex, England. She wrote two published works: A Discourse Concerning the Love of God (1696) and Occasional Thoughts in Reference to a Vertuous or Christian Life (1705). She is particularly noted for being one of the earliest advocates for women's education. Masham regularly corresponded with Leibniz in the years between 1704 and 1706. In these letters, mostly metaphysical problems were presented: the nature of substance and pre-established harmony.

Keywords: Damaris Masham, Gottfried Wilhelm Leibniz, John Locke, metaphysics, substance, women education

\section{Streszczenie}

\section{Damaris Masham, jej związki z Johnem Lockiem i dyskusja z Gottfriedem Wilhelmem Leibnizem}

Artykuł przedstawia sylwetkę i poglądy siedemnastowiecznej myślicielki Damaris Masham, żywo zainteresowanej współczesną sobie filozofią, jak również kwestiami teologicznymi i społecznymi.

Damaris Masham (1659-1708) była córką Ralpha Cudwortha, filozofa z kręgu tak zwanych platoników z Cambridge oraz przyjaciółką Johna Locke’a, który ostatnie lata swego życia spędził w jej domu w Oates. Napisała dwie wydane drukiem rozprawy: A Discourse Concerning the Love of God (1696) oraz Occasional Thoughts in Reference to a Vertuous or Christian Life (1705). Znana jest głównie jako propagatorka kształcenia kobiet. W latach 1704-1705 korespondowała regularnie z G. W. Leibnizem. W listach podejmowana była przede wszystkim problematyka dotycząca metafizyki: substancja, przedustawna harmonia.

Słowa kluczowe: Damaris Masham, Gottfried Wilhelm Leibniz, John Locke, metafizyka, substancja, edukacja kobiet 